\title{
USAGE OF INTRAMAMMARY ANTIMICROBIAL VETERINARY MEDICINAL PRODUCTS IN THE REPUBLIC OF SERBIA FROM 2011 TO 2014
}

Jelena Andjelkovic ${ }^{1}$, Vesela Radonjic ${ }^{2}$

${ }^{1}$ Veterinary Medicines Department, Medicines and Medical Devices Agency of Serbia; ${ }^{2}$ National Centre for Information on Medicines and Medical Devices, Medicines and Medical Devices Agency of Serbia; Faculty of Medical Sciences, University of Kragujevac

\section{PROMET VETERINARSKIH INTRAMAMARNIH ANTIBIOTIKA U REPUBLICI SRBIJI OD 2011. DO 2014. GODINE \\ Jelena Anđelković ${ }^{1}$, Vesela Radonjić ${ }^{2}$ \\ ${ }^{1}$ Veterinarski sektor, Agencija za lekove i medicinska sredstva Srbije; \\ ${ }^{2}$ Nacionalni centar za informacije o lekovima i medicinskim sredstvima, Agencija za lekove i medicinska sredstva Srbije; Fakultet medicinskih nauka, Univerzitet u Kragujevcu}

Received / Primljen: 07. 06. 2016.

Accepted / Prihvaćen: 09. 07. 2016.

\begin{abstract}
Prudent use of antimicrobial medicine is an imperative in both human and veterinary medicine today. Antibiotic usage in humans and animals has increased over the years, consequently giving rise to antimicrobial resistance in pathogenic microorganisms. Mastitis is one of the most common conditions in bovine species, and intramammary antibacterial medicinal products are used in animal husbandry for mastitis treatment and prophylaxis.

This paper presents the quantities of intramammary antibiotics sold in the Republic of Serbia from 2011 to 2014 based on data reported to the Medicines and Medical Devices Agency of Serbia by Marketing Authorization Holders. Furthermore, we assessed the number of treated cows and compared those results with the reported total number of cows in the same time period, providing information on animal exposure to particular antibiotics.

In 2011 and 2012, beta-lactams were the most commonly used antimicrobials, while beta-lactams in combination with other substances were the most commonly used antibiotics in 2014, with a total of 80,927 treated animals. From 2011 to 2014, 15-25\% of cows were treated with intramammary antimicrobials.

Bearing in mind the growing importance of antibiotic resistance in humans and animals, these results reveal the scope of the potential human exposure to antibiotics via consumption of the milk of treated cows.
\end{abstract}

Keywords: mastitis, intramammary antibacterial agents, veterinary medicinal product, resistance

\section{SAŽETAK}

Odgovorna primena antimikrobnih lekova danas je jedan od imperativa $u$ humanoj $i$ veterinarskoj medicini. Primena antibiotika kod ljudi $i$ životinja je u porastu, što posledično dovodi do razvoja rezistencije na antibiotike kod patogenih mikroorganizama. Mastitis je jedno od najčešcih stanja kod goveda, te se intramamarni antibiotski lekovi primenjuju u lečenju i profilaksi mastitisa.

Ovaj rad prezentuje količine intramamarnih antibiotika koje su se nalazile u prometu u Republici Srbiji u periodu od 2011. do 2014. godine, a na osnovu podataka dostavljenih Agenciji za lekove i medicinska sredstva Srbije od strane nosilaca dozvole za lek. Pored toga, ovaj rad procenjuje broj tretiranih krava u istom vremenskom periodu, čime pruža podatke o izloženosti životinja pojedinim antibioticima.

U 2011. i 2012. godini najčešće su primenjivani beta-laktamski antibiotici, dok su tokom 2014. godine najčešće primenjivani beta-laktamski antibiotici u kombinaciji sa drugim supstancama sa 80927 lečenih životinja. Izmedu 15\% i 25\% krava lečeno je intramamarnim antibioticima u periodu od 2011. do 2014. godine.

Imajući u vidu sve veći značaj rezistencije na antibiotike kod ljudi i životinja, ovi rezultati mogu ukazati na obim potencijalnog izlaganja ljudi antibioticima putem korišćenja mleka lečenih krava.

Ključne reči: mastitis; intramamarni antibiotik, veterinarski lek, rezistencija 


\section{INTRODUCTION}

People, animals, and the environment represent an interconnected, dynamic system. One health initiative aims towards better understanding and addressing contemporary health issues created by the convergence of humans, animals, and environmental domains (1). Antimicrobial medicinal products are essential for treating infections in both humans and animals. Globally, an estimated $50 \%$ of all antimicrobials are used in veterinary medicine. Additionally, in animals antibiotic use is the primary contributor to the selection and spread of antimicrobial resistance. Animals and humans share the same antibiotic resistance mechanisms (2). Antimicrobial resistance is regarded as one of the major threats to the future health of individuals and populations, and national and international organizations have repeatedly underlined an urgent need for action (3). It is essential to monitor trends in the consumption of antibiotics to identify the risk factors that contribute to the spreading of the resistance (4).

Mastitis is a major challenge to the worldwide dairy industry (5). Modern farming practice widely employs intramammary antimicrobial medicines in dairy production since intramammary infections are one of the most common conditions in bovine species (6). Mastitis is an inflammation of the mammary gland, usually caused by pathogenic microorganisms (7). The disease is followed by a complex series of events leading to reduced synthetic activity, compositional changes, and elevated somatic cell count, all affecting milk production and quality. Escherichia coli and Streptococcus uberis are the microorganisms most frequently isolated in bovine mastitis (5).

Intramammary antibiotics are used both for the treatment and prevention of mastitis in cattle. In cows with clinical mastitis, the treatment outcome depends on the host, bacterial and management factors as well as on the selected antimicrobial medicine (8). When used for mastitis treatment, immediate release formulations are administered during lactation. Such medicines are administered only into the affected teat, and milk should be discarded during a brief time period, usually for several days. In contrast, long-acting formulations are administered during the dry period into all quarters. These medicines are used as a prophylactic treatment of mastitis in herds where subclinical mastitis is present. Long-acting preparations have long withdrawal periods, which can last as long as 60 or more days, depending on the time between dry-off and calving.

Allergy to antimicrobial medicines, especially to $\beta$-lactams, is a well-established adverse effect in human medicine. Sensitive persons can be exposed to antimicrobials through food, especially milk and dairy products (9). Not only does this instigate a human health hazard, but the residues of antimicrobial medicines in milk can be a problem in the dairy industry (10) since antibiotics disable the fermentation of microorganisms used in manufacturing of dairy products such as cheese and yogurt. Therefore, the judicious use of antimicrobials in food-producing animals, compliance with prescribed withdrawal periods and strict monitoring of drug residues are essential for the safety of both humans and animals.

In this paper, we presented the quantities of intramammary antibiotics sold in the Republic of Serbia. Furthermore, we estimated the number of cows treated with these medicines and compared this number with the reported total number of cows.

\section{MATERIALS AND METHODS}

The Medicines and Medical Devices Agency of Serbia annually collects information on medicinal sales from Marketing Authorization Holders. Those quantities are presented according to ATCvet classification of the World Health Organization (11). A review of such information for 2014, prepared for the general public, is available on the Agency's website (12).

ATCvet classification has become the gold standard for international drug utilization research. It classifies active substances according to system organ class, therapeutic indication and chemical properties. The European Medicines Agency published the Principles on assignment of defined daily dose for animals (DDDvet) in 2015 and defined the course dose for animals (DCDvet) (13). Since DDDvet and DCDvet are technical units, they are intended for the investigation of medicinal consumption. When medicinal products are used during lactation, they are used for the treatment of the affected quarter, and the treatment lasts for two to four days; therefore, such products have been assigned only with DDDvet. When intramammary medicines are administered at dry-off, they are administered concomitantly into all quarters as a single treatment, and they have been assigned with DCDvet only. However, we chose not to present our findings in accordance with these principles because we could not calculate the number of animals exposed to intramammary antimicrobials in the Serbian market in such a manner. DDDvet and DCDvet are calculated on the basis of the usual posology for certain active substances and do not reflect individual variations in authorized posology for medicines containing the same active substances. Therefore, we used data from authorized Summaries of Product Characteristics for each of these products and calculated the number of treatments. On the basis of these data, we estimated the number of cows exposed to intramammary antimicrobial treatment and compared those figures with the total number of cows in the Republic of Serbia, as reported by the Statistical Office of the Republic of Serbia (14). In this way, we could determine the approximate number of treated cows for a certain year, reducing possible errors arising from variations in posology to a minimum. All calculations were performed in Microsoft Office Excel 2007. 


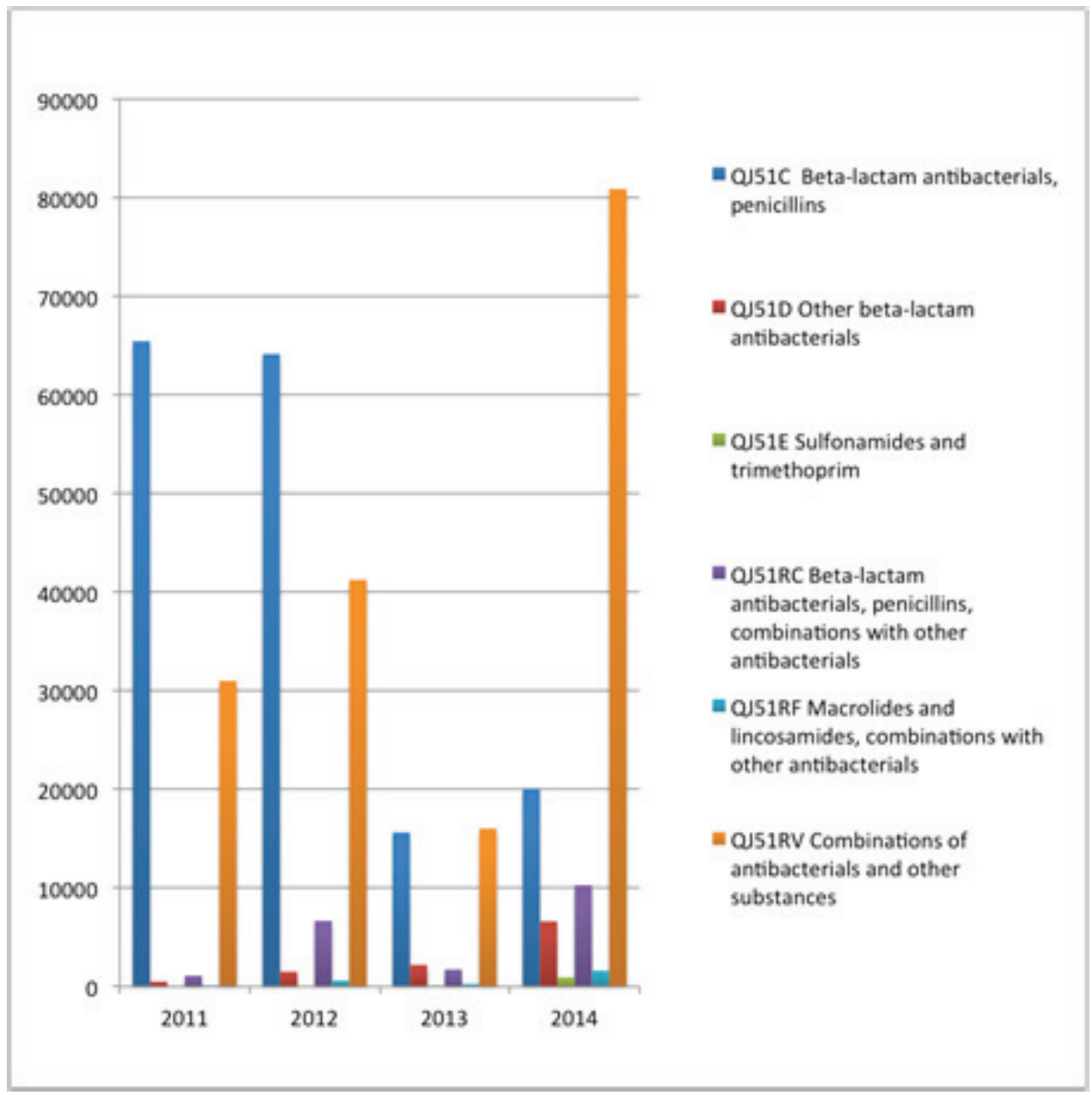

Figure 1: Number of packages sold per ATCvet code

\section{RESULTS}

From 2011 to 2014, in the Republic of Serbia, there were between 19 and 25 intramammary antimicrobial medicines with Marketing Authorization $(15,16)$. In the same time period, there were between 451,000 and 509,000 cows in the Republic of Serbia (Table 1). Figure 1 presents the number of packages sold per ATCvet code. Beta-lactam antibiotics from the penicillin group accounted for most packages sold in 2011 and 2012 (65,489 and 64,180 packages, respectively), while antibacterials in combination with other substances were the most used intramammary medicinal products in 2013 and 2014 (16,033 and 80,927 packages, respectively).

Figure 2 presents the number of treated cows in the Republic of Serbia, calculated based on information available from the authorized Summary of Product Characteristics. The total number of treated cows varies between 68,900 animals in 2013 and 120,473 animals in 2012, most of them treated during lactation (44,777 animals in 2013 and 90,129 animals in 2012). As shown in this figure, the number of treated cows corresponded to the number of cows treated during lactation, but the number of cows treated during the dry period gradually declined, from 28,235 in 2011 to 14,110 in 2014. Additionally, we observed
Table 1: Number of registered intramammary antimicrobials and number of cows in 2011-2014

\begin{tabular}{|l|c|c|}
\hline & $\begin{array}{c}\text { Number of registered intra- } \\
\text { mammary antimicrobials }\end{array}$ & Number of cows \\
\hline $\mathbf{2 0 1 1}$ & 21 & 509000 \\
\hline $\mathbf{2 0 1 2}$ & 25 & 480000 \\
\hline $\mathbf{2 0 1 3}$ & 19 & 451000 \\
\hline $\mathbf{2 0 1 4}$ & 24 & 460000 \\
\hline
\end{tabular}

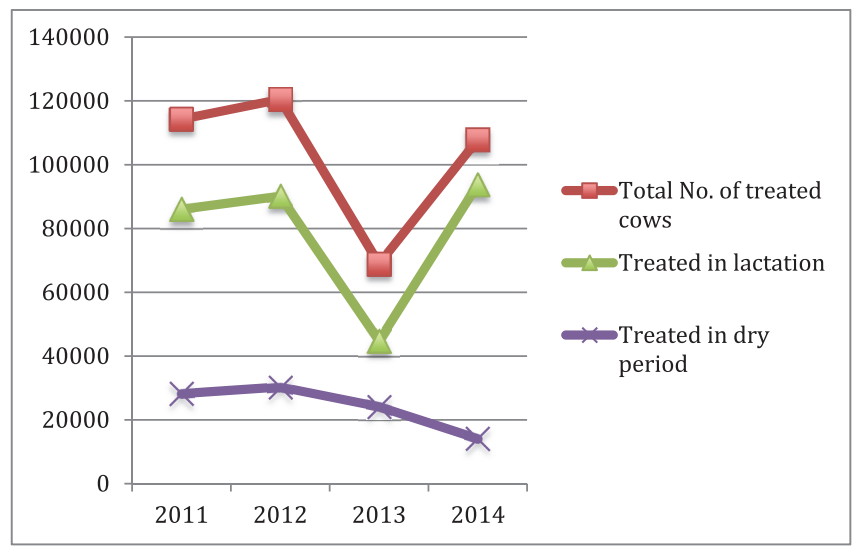

Figure 2: Number of treated cows in RS 


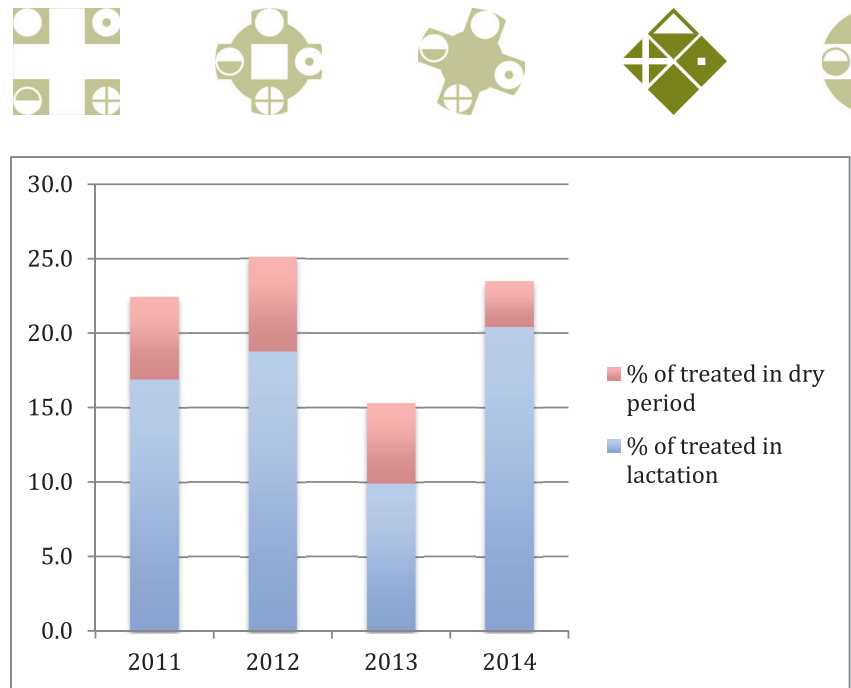

Figure 3: Percentage of treated cows in comparison to total number of cows in RS

that variation in the number of treatments between 2012 and 2013 was the result of variation in the sales of products used during lactation and not in the dry period.

As presented in Figure 3, the percentage of cows treated with intramammary antibiotics compared to the total number of cows in the Republic of Serbia varied between $15 \%$ and $25 \%$. This meant that possibly $15 \%$ to $25 \%$ of milk might contain residues resulting from administration of intramammary antibiotics. This is not the final percentage because a number of animals received parenteral antimicrobial treatment. The percentage of cows treated during the dry period was approximately $5 \%$ over the first three years of monitoring (5.3\%-6.3\%), but the percentage declined to just above 3\% in 2014 .

The number of treatments per ATCvet group is presented in Figure 4. Beta-lactams, used as a single agent or in combination with other substances, were the most used intramammary products in the Republic of Serbia. In $2014,80,927$ cows were treated with beta-lactams in combination with other substances (ATCvet code QJ51RV). Sulphonamides and trimetoprim were the least used intramammary antibiotics, with only 119 treatments in 2013 and 952 treatments in 2014. Macrolides and lincosamides were also infrequently used, with 103 treatments in 2011, increasing to 1626 treatments in 2014.

\section{DISCUSSION}

As our research showed, up to $25 \%$ of cows in the Republic of Serbia were treated with intramammary antibiotics over one year. Most of those antibiotics were beta-lactams, whose sensitizing potential is well known. Therefore, prudent use of intramammary antimicrobials is necessary for preserving the health of both animals and humans.

Finding that beta-lactams are the most commonly used intramammary products in the Republic of Serbia was in line with findings from the Danish Integrated Antimicrobial Resistance Monitoring and Research Program (DANMAP) (4), whose report stated that beta-lactama-

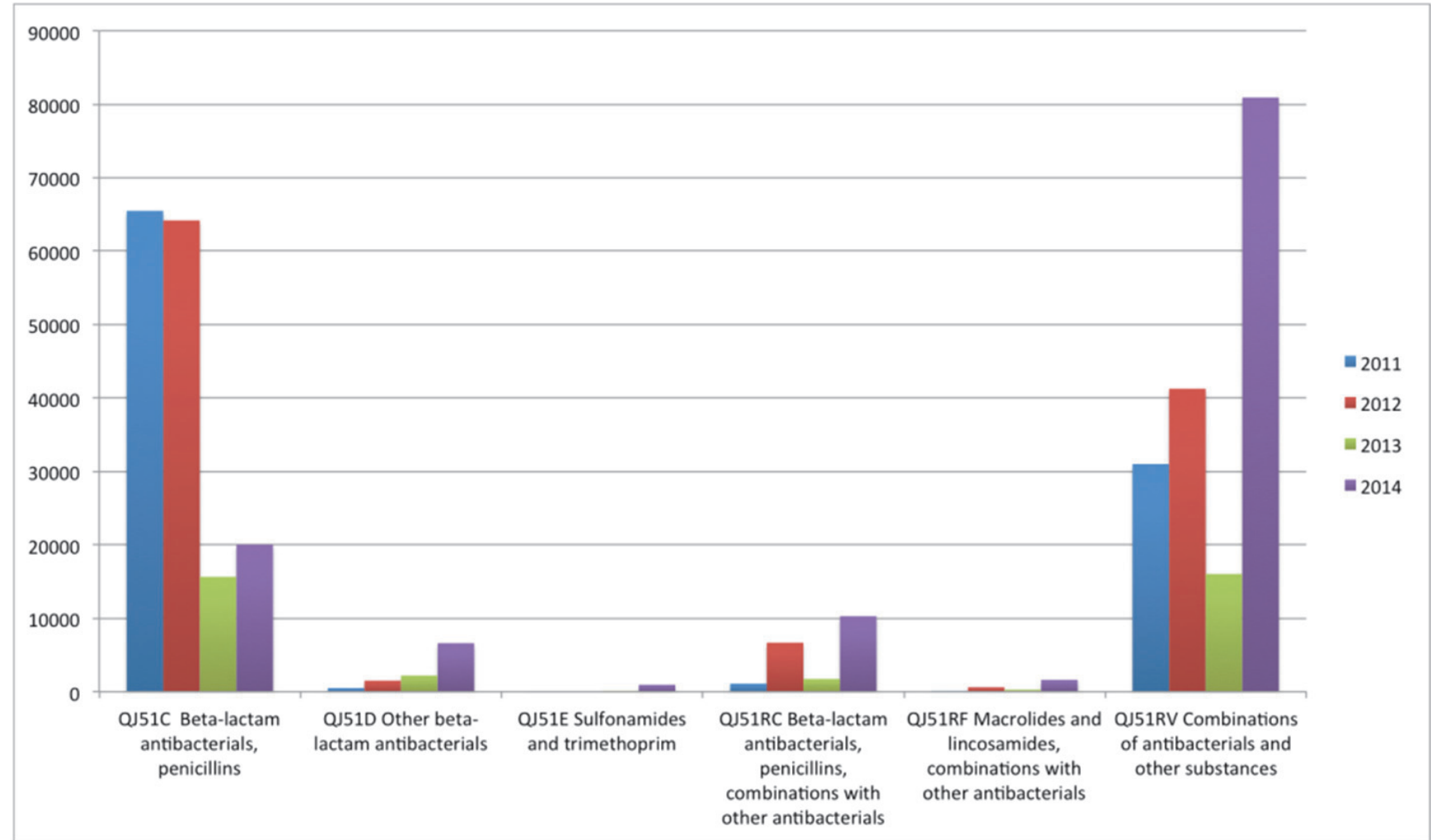

Figure 4: Number of treatments per ATCvet group 
se-sensitive penicillin accounted for the majority of antimicrobial consumption in Denmark for the reported time period (2005-2014). It is likely that the results of "milk quality campaign", conducted by the Danish Cattle Association (Agriculture and Food Council) since 2010, aimed to reduce treatment of clinical mastitis by $50 \%$. Furthermore, Order (DK) 785/2010 provided legal regulations on the use of antimicrobial agents for mastitis in cattle (recommending using simple penicillin).

As shown in Figure 1, the number of sold packages varied greatly. This variation could be explained by the fact that Marketing Authorization holders report the number of sold packages of medicinal products to the Medicines and Medical Devices Agency of Serbia on a yearly basis. Larger quantities of medicinal product sold during one year might be the cause of smaller quantities of the same medicinal product sold during the next year. These differences can be observed for 2012 and 2013, when large quantities were on the market in 2012, followed by significantly smaller quantities in 2013.

It was also shown that beta-lactam antibacterials (ATCvet group QJ51C) were the most frequently used intramammary antibiotics in 2011 and 2012, which significantly differs from data for 2013 and 2014, when most packages sold were from group QJ51RV, combinations of antibacterials and other substances. Those other substances are usually steroidal hormones used to reduce inflammation. The reason for this switch from beta-lactams to combination therapies is likely due to because one large domestic manufacturer discontinued the manufacturing of veterinary medicines, including intramammary ones, and other medicine manufacturers took over the market.

Furthermore, the number of sold packages does not reflect the number of treated cows since some medicinal packages contain 20 or more intramammary injectors and others contain a single injector in the package. The posology also differs, and such information is available in the Summary of Product Characteristics (SmPC) for each registered product. For that reason, to determine the exposure of the animal population to intramammary antibiotics, it was necessary to calculate the number of treated cows to estimate the exposure of animals to such medicines. However, these figures are not final and represent only an approximate value since they are based on medicinal quantities reported by Marketing Authorization Holders. Collecting data from veterinary institutions and end users could provide more accurate information on medicine usage.

These results provide important information about exposure of cattle to certain antibiotics and, therefore, direct future research towards investigating a linkage between antibiotic resistance and administration of intramammary veterinary medicinal products. Beta-lactams are the most frequently used intramammary antimicrobials in the Republic of Serbia and, therefore, their residues represent a major concern that needs to be closely monitored and further investigated.

\section{REFERENCES}

1. King LJ, Anderson LR, Blackmore CG, Blackwell MJ, Lautner EA, Marcus LC, Meyer TE, Monath TP, Nave JE, Ohle J, Pappaioanou M. Executive summary of the AVMA one health initiative task force report. Journal of the American Veterinary Medical Association. 2008 Jul 15;233(2):259-61.

2. Teuber M. Veterinary use and antibiotic resistance. Current opinion in microbiology. 2001 Oct 1;4(5):493-9.

3. Littmann J, Viens AM. The Ethical Significance of Antimicrobial Resistance. Public health ethics. 2015 Sep 30:phv025.

4. Bager F, Birk T, Høg BB, Jensen LB, Jensen AN, de Knegt L, Korsgaard H, Dalby T, Hammerum A, Hoffmann S, Kuhn KG. DANMAP 2014-Use of antimicrobial agents and occurrence of antimicrobial resistance in bacteria from food animals, food and humans in Denmark.

5. Bradley AJ. Bovine mastitis: an evolving disease. The Veterinary Journal. 2002 Sep 30;164(2):116-28.

6. Gruet P, Maincent P, Berthelot X, Kaltsatos V. Bovine mastitis and intramammary drug delivery: review and perspectives. Advanced drug delivery reviews. 2001 Sep 1;50(3):245-59.

7. Harmon RJ. Physiology of mastitis and factors affecting somatic cell counts. Journal of dairy science. 1994 Jul 31;77(7):2103-12.

8. Craven N. Efficacy and financial value of antibiotic treatment of bovine clinical mastitis during lactation-a review. British Veterinary Journal. 1987 Oct 31;143(5):410-22.

9. Dewdney JM, Maes L, Raynaud JP, Blanc F, Scheid JP, Jackson T, Lens S, Verschueren C. Risk assessment of antibiotic residues of $\beta$-lactams and macrolides in food products with regard to their immuno-allergic potential. Food and Chemical Toxicology. 1991 Dec 31;29(7):477-83.

10. Jones GM, Seymour EH. Cowside antibiotic residue testing. Journal of dairy science. 1988 Jun 30;71(6):1691-9.

11. World Health Organization. WHO collaborating centre for drug statistics methodology. ATCvet index 2016.

12. Medicines and Medical Devices Agency of Serbia. Consumption of Veterinary Medicines. Review for 2014. Retrieved from http://www.alims.gov.rs/ciril/ files/2015/12/vet-promet2014.pdf

13. European Medicines Agency. Principles on assignment of defined daily dose for animals (DDDvet) and defined course dose for animals (DCDvet). Retrieved from http://www.ema.europa.eu/docs/en_GB/document_library/Scientific_guideline/2015/06/WC500188890.pdf

14. Statistical Office of the Republic of Serbia, database available at http://webrzs.stat.gov.rs

15. Medicines and Medical Devices Agency of Serbia.National Veterinary Medicines Formulary. Belgrade: NIJANSA d.o.o.; 2011

16. Medicines and Medical Devices Agency of Serbia National Veterinary Medicines Formulary. Retrieved from http://www.alims.gov.rs/ciril/files/2014/08/NRLvet2014-sve.pdf 


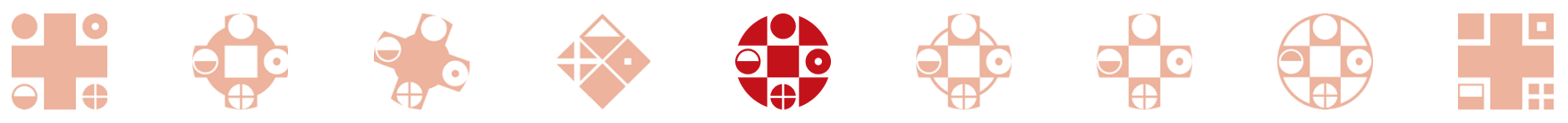

